\title{
Prevalence of Gastro-Intestinal Nematodiasis in Goat at Sylhet Sadar Upazilla, Sylhet, Bangladesh
}

\author{
Md. Nazrul Islam ${ }^{1}$, Md. Rafiqul Islam², Kazi Mehetazul Islam ${ }^{3}$, A.H.M. Musleh Uddin ${ }^{4}$, \\ Md. Irtija Ahsan ${ }^{5}$
}

${ }^{1}$ Nourish Poultry and Hatchery Ltd., Uttara, Dhaka-1230, Bangladesh; ${ }^{2}$ Department of Medicine, Faculty of Veterinary, Animal and Biomedical Sciences, Sylhet Agricultural University, Sylhet-3100, Bangladesh; ${ }^{3}$ Department of Parasitology, Faculty of Veterinary, Animal and Biomedical Sciences, Sylhet Agricultural University, Sylhet-3100, Bangladesh; ${ }^{4}$ Department of Surgery and Theriogenology, Faculty of Veterinary, Animal and Biomedical Sciences, Sylhet Agricultural University, Sylhet-3100, Bangladesh; ${ }^{5}$ Department of Epidemiology and Public Health, Faculty of Veterinary, Animal and Biomedical Sciences, Sylhet Agricultural University, Sylhet-3100, Bangladesh.

\begin{abstract}
A cross-sectional study was carried out from June 2015 to November 2015 taking 150 faecal samples collected from 150 randomly chosen goats following simple random sampling from Sylhet Sadar upazilla of Sylhet district to explore the prevalence of gastro-intestinal nematodiasis (GIN). From the collected faecal samples EPG of nematodal species was counted by simple McMaster technique using saturated salt and sugar solution. A goat was considered having GIN if one gram of its faeces contains $\geq 50$ eggs of one or more nematodal species. The overall prevalence of GIN was 82.66\% (95\% CL: 76.54-88.79) in goat. In respect of age, $86.51 \%$ young ( $\leq 2$ years) and $77.04 \%$ adult ( $>2$ years) were found infected with GIN. The prevalence was observed $80.41 \%$ in female while $86.79 \%$ in male in this study. Therefore, it may infer that the prevalence of GIN was exceedingly high in goat reared at Sylhet Sadar upazilla and require effective control regime.
\end{abstract}

Keywords | Prevalence, Goat, Nematodiasis, Sylhet, Bangladesh

\begin{abstract}
Editor $\mid$ Muhammad Imran Rashid, Department of Parasitology, University of Veterinary and Animal Sciences, Lahore, Pakistan.
Received | December 24, 2018; Accepted | February 06, 2019; Published | April 16, 2019

*Correspondence $\mid$ Md. Irtija Ahsan, Department of Epidemiology and Public Health, Faculty of Veterinary, Animal and Biomedical Sciences, Sylhet Agricultural University, Sylhet-3100, Bangladesh; Email: irtijaa.eph@sau.ac.bd

Citation | Islam MN, Islam MR, Islam KM, Uddin AHMM, Ahsan MI (2019). Prevalence of gastro-intestinal nematodiasis in goat at sylhet sadar upazilla, sylhet, bangladesh. J. Adv. Parasitol. 6(2): 12-15.

DOI | http://dx.doi.org/10.17582/journal.jap/2019/6.2.12.15
\end{abstract}

Copyright $(\underset{0}{2019}$ Islam et al. This is an open access article distributed under the Creative Commons Attribution License, which permits unrestricted use, distribution, and reproduction in any medium, provided the original work is properly cited.

\section{INTRODUCTION}

$\mathrm{G}$ astro-intestinal nematodiais (GIN), caused by nematodes occupying and affecting GI tract, is considered as one of the major constraints of livestock production and economy worldwide (Vercruysse and Claerebout, 2001). Like other animals, goats are highly susceptible to GIN facing a considerable health hazard and reduced productive performances throughout the world due to the associated morbidity, mortality and cost of treatment and control measures (Iqbal et al., 1993). The most important GI nematodal species for goats include Haemonchus contortus, Oesophagostomum spp., Ostertagia spp., Nematodirus spp.,
Moniezia spp. and Trichuris ovis. Severely infected goats suffer from unthriftiness and anorexia resulting decrease in body weight, birth weight and dystocia. The condition worsens and prognosis becomes too poor when blood sucking GI nematodes infect young while adult develops anaemia (Husnain and Usmani, 2006). Goat rearing, very popular in Bangladesh with total population is 25.12 million, plays a key role in socio-economic development and meeting up protein deficit (BER, 2012). Unfortunately, the progress of goat farming is in threat due to many hazardous infectious diseases including GIN. Kamal et al. (1993) and Nahar et al. (2012) reported the prevalence of GIN in Chittagong and Rajshahi district, respectively. 
The study area, Sylhet Sadar upazilla, located at the heart of Sylhet district and in the north-east of Bangladesh, is very prospective for goat rearing due to its geo-climatic condition. The topography hot and humid summer as well as relatively cool weather of this upazilla create a favorable environment for the survival of various parasites with their intermediate hosts (Sahlu et al., 2009; Wikipedia, 2014) and goats mostly raised either semi-intensive or free ranging grazing system increasing the chance of contact with the causal agents and intermediate hosts. GIN is supposed to be a common problem and strong barrier for goat rearing in this upazilla. However, the epidemiology of GIN has yet remained undisclosed at this upazilla needed for planning of successful control strategies. Therefore, this study was undertaken to estimate the prevalence of GIN in goat at this upazilla.

\section{MATERIALS AND METHODS}

\section{Study Area}

The study was conducted at Sylhet Sadar upazilla under Sylhet district of Bangladesh possessing sub-tropical climate covering an area of 301.80 sq. km. including 5.84 sq. km. 8.10 sq. km. river and forest areas, respectively. It is geographically positioned between $24^{\circ} 43^{\prime}$ and $24^{\circ} 77^{\prime}$ north latitude and between $91^{\circ} 40^{\prime}$ and $91^{\circ} 01^{\prime}$ east longitudes and surrounded by Companiganj and Gowainghat upazillas in the north, Golapganj and Jaintiapur upazillas in the east, Dakshin Surma upazilla in the south and Chatak upazilla of Sunamganj district and Bishwanath upazilla in the west (BBS, 2013).

\section{Study Design}

Cross-sectional study design was used in this study during June 2015 to November 2015 to determine the prevalence of GIN in goat at Sylhet Sadar upazilla of Sylhet district.

\section{Target Population and Sample Size \\ Calculation}

Total goat population at Sylhet Sadar upazilla was the target population. Only from the Sylhet Government Goat Developing Farm, situated at this upazilla, goats were circulated as well as sold for rearing throughout the study area and Akanda et al. (2012) reported the prevalence of GIN was $100 \%$ at this farm. Therefore, considering expected prevalence ( $p$ ) as $1,95 \%$ confidence level (z) as 1.96 and desired absolute precision (d) as 0.05 , the sample size was calculated as zero by using the following formula for estimating prevalence according to Thrusfield (2005). So, from the target population 150 goats were randomly selected us- ing simple random sampling scheme by computerized random number generator as a representative portion which was supposed to be rational considering the circumstances. Age of the goat was defined by examining teeth as suggested by Rahman and Hossain (1997) and sex was identified observing the presence of penis or uterus (Hossain et al., 2011).

$n=\frac{z^{2} p(1-p)}{d^{2}}$

\section{Collection of Fecal Sample}

A twenty gram of faecal sample was collected aseptically from the rectum through index figure from each of the selected goats. A separate labeled mini plastic container was used to keep individual faecal sample then placed into icebox at $8^{\circ} \mathrm{C}$ and transported to the Medicine laboratory of Sylhet Agricultural University, Sylhet and stored in a refrigerator under $4{ }^{\circ} \mathrm{C}$.

\section{Faecal Sample Examination and Determination of Nematodal Species}

Simple McMaster technique with saturated salt and sugar solution, described by Permin and Hansen (1998), was employed to examine collected faecal samples for the identification of nematodal species based morphological characters of their eggs (Soulsby, 1982) and quantification of EPG.

\section{Statistical Analysis}

The data from animal source (age and sex) and laboratory work was firstly entered into Microsoft excel spread sheet and coded for analysis. Goats were divided into two age groups, namely, young ( $\leq 2$ years) and adult ( $>2$ years) according to strategy devised by Nahar et al. (2012) with some modification. A case definition was used based on EPG, suggested by Permin and Hansen (1998), to define a goat either having GIN or not; if a gram of faeces of a goat contained $\geq 50$ eggs of one or more nematodal species, then that goat was considered to be positive for GIN. The prevalence was determined as a proportion of GIN positive goats among sampled goats. The precision of the estimate was authenticated by calculating 95\% Confidence Limit (CL) of proprortion. The analysis was performed using statistical software packages SPSS (version 15.2) and SAS (version 9.4).

\section{RESULTS}

\section{Overall Prevalence of GiN}

Among 150 samples, we found 124 samples having one or more eggs of one or more nematodes, hence, overall prevalence of GIN was $82.66 \%$ (95\% CL: 76.54-88.79) in goat at Sylhet Sadar upazilla under 
Table 1: Overall and sex wise prevalence of GIN estimated from 150 faecal samples of 150 randomly selected goats from Sylhet Sadar during Juneto November 2015

\begin{tabular}{|lllll|} 
Sex & No. of goat examined & No of goat positive for GIN & Prevalence (\%) & 95\% Confidence Limit \\
\hline Female & 97 & 78 & 80.41 & $72.37-88.45$ \\
\hline Male & 53 & 46 & 86.79 & $77.37-96.21$ \\
\hline Total (Overall) & 150 & 124 & 82.66 & $76.54-88.79$
\end{tabular}

Table 2: Age wise prevalence of GIN estimated from 150 faecal samples of 150 randomly selected goats

\begin{tabular}{|c|c|c|c|c|c|c|}
\hline \multirow{2}{*}{ Sex } & \multicolumn{3}{|c|}{ Young ( $\leq 2$ years) } & \multicolumn{3}{|c|}{ Adult (>2years) } \\
\hline & $\begin{array}{l}\text { No. of goat } \\
\text { examined }\end{array}$ & $\begin{array}{l}\text { No. of goat posi- } \\
\text { tive for GIN }\end{array}$ & $\begin{array}{l}\text { Prevalence (\%) (95\% } \\
\text { Confidence Limit) }\end{array}$ & $\begin{array}{l}\text { No. of goat } \\
\text { examined }\end{array}$ & $\begin{array}{l}\text { No. of goat } \\
\text { positive for } \\
\text { GIN }\end{array}$ & $\begin{array}{l}\text { Prevalence (\%) (95\% } \\
\text { Confidence Limit) }\end{array}$ \\
\hline Female & 52 & 44 & $\begin{array}{l}84.61 \\
(74.47-94.76)\end{array}$ & 45 & 34 & $\begin{array}{l}75.55 \\
(62.50-88.61)\end{array}$ \\
\hline Male & 37 & 33 & $\begin{array}{l}89.18 \\
(78.69-99.69)\end{array}$ & 16 & 13 & $\begin{array}{l}81.25 \\
(59.77-100.00)\end{array}$ \\
\hline Total & 89 & 77 & $\begin{array}{l}86.51 \\
(79.28-93.75)\end{array}$ & 61 & 47 & $\begin{array}{l}77.04 \\
(66.20-87.91)\end{array}$ \\
\hline
\end{tabular}

Sylhet distrct of Bangladesh (Table 1).

\section{Sex Wise Prevalence of GiN}

Among 150 randomly selected goats, numbers of male and female were 97 and 53, respectively of which 78 males and 46 females were found to have GIN resulting prevalence $86.79 \%$ in male whereas $80.11 \%$ in female (Table 1).

\section{Age Wise Prevalence of GiN}

According to the definition of category of age groups, from 150 chosen goats numbers of young and adult were 89 and 61, respectively. The numbers of positive young and adults were noted 77 and 47, correspondingly. Therefore, the prevalence of GIN was $86.51 \%$ in young while $77.04 \%$ in adult. Again among the young $89.18 \%$ male and $84.61 \%$ female were affected with GIN whereas among adult prevalence was $81.25 \%$ and $75.55 \%$ in male and female, respectively (Table 2).

\section{DISCUSSION}

Present study revealed that the prevalence of GIN was $82.66 \%$ in goat at Sylhet Sadar upazilla in Sylhet district of Bangladesh. But this high prevalence was not unpredicted. The geo-climatic condition suits the survival of various parasites and their intermediate hosts in this region. Besides goats rose in semi-intensive and free ranging rearing system that allow them to expose to various parasites and increase the risk of being infected. These might contribute to such high prevalence, even $100 \%$ prevalence of GIN was found by Akanda et al. (2012) in goat from Sylhet Government Goat Development Farm located at this upazilla. This finding also agrees with the finding of Kamal et al. (1993) who reported $78.41 \%$ prevalence in Chittagong district of Bangladesh having geo-climatic resemblance with the study area. High prevalence of GIN was also reported from neighbouring country India $(86.80 \%)$ by Yadav and Tandon (1989).

Current study disclosed that, GIN was more prevalent in male than female. This is might be due the immunosuppressive activity of Androden and Testosterone in male to GI nematodes (Barger et al., 1993; Seli and Arici, 2002). The results of the present study are also line with the findings of Nabi et al. (2014) who found higher prevalence of GIN in male than female.

In this study, the higher prevalence of GIN was obtained in young than adult. Higher prevalence in young animals can be contributed due to contaminated environment, over stocking, lack of immunity and relation between age and immunity that is young animals are more susceptible than adult (Biu et al., 2009). This might be another reason of such fingdings. The results of this study are also in accordance with finding of Nabi et al. (2014).

\section{ACKNOWLEDGEMENTS}

The authors would like to thank the respondents for participating in this study and the laboratory staff for maintenance of laboratory arrangement. This research did not receive any specific grant from funding agencies in the public, commercial, or not-for-profit sectors. 


\section{CONFLICT OF INTEREST}

The authors confirm that there is no conflict of interests.

\section{AUTHORS CONTRIBUTION}

Md. Nazrul Islam developed the conception and design of the study. He also collected data and fecal samples, and did laboratory examination of fecal samples. Md. Rafiqul Islamand Kazi Mehetazul Islam had substantial contributions to design of the work with overall supervision. A. H. M. Musleh Uddin helped in data collection and laboratory examination of fecal samples.Md. Irtija Ahsan performed data analysis, drafted and revised the manuscript critically from the Thesis for intellectual content, and did necessary corrections.

\section{REFERENCES}

- Akanda MR, Hossain FMA, Uddin MN, Belal SA, Ashad F, Howlader MMR (2012). Prevalence of gastrointestinal nematodiasis in Black Bengal goat of Sylhet Govt. Goat Development Farm, Bangladesh. J. Res. Biol. 2(3): 246-250.

- Barger IA (1993). Influence of sex and reproductive status on susceptibility of ruminants to nematode parasitism. Int. J. Parasitol. 23(4): 463-469. https://doi.org/10.1016/00207519(93)90034-V

- BBS (2013). Population and Housing sensus 2011. Bangladesh Bureau of Statistics, p 52.

- BER (2012). Bangladesh Economic Review 2012, p 111.

- Biu AA, Maimunatu A, Salamatu AF, Agbadu ET (2009). A fecal survey of gastrointestinal parasites of ruminants in the University of Maiduguri Research Farm. Int. J. Biomed. Health Sci. 5(4): 175-179.

- Hossain MM, Paul S, Rahman MM, Hossain FMA, Hossain MT, Islam MR (2011). Prevalence and economic significance of caprine fascioliasis at Sylhet district of Bangladesh. Pak. Vet. J. 31(2): 113-116.

- Husnain HU, Usmani RH (2006). Livestock of Pakistan. Livestock Foundation, Islamabad, Pakistan. Pp 154.

- Iqbal Z, Akhtar M, Khan MN, Riaz M (1993). Prevalence and economic significance of haemonchosis in sheep and goat slaughtered at Faisalabad abattoirs. Pak. J. Agri. Sci. 30(1): 51-53.

- Kamal AHM, Uddin KH, Rahman ML (1993). Prevalence of gastro-intestinal nematodes in goat at chittagong hilly areas of Bangladesh. Asian Australas. J. Anim. Sci. 6(3): 343-345. https://doi.org/10.5713/ajas.1993.343

- Nabi H, Saeed K, Shah SR, Rashid MI, Akbar H, Shehzad W (2014). Epidimiological study of gastrointestinal nematodes of goats in district swat, Khyber pakhtunkhwa, Pakistan. Sci. Int. 26(1): 283-286.

- Nahar L, Sarder MJU, Mondal MMH, Faruquw MO, Islam MH (2012). Factors related occurrence of Haemonchosis of Goats in Rajshahi, Bangladesh. Int. J. Nat. Sci. 2(1): 83-87. https://doi.org/10.3329/ijns.v2i3.12137

- Permin A, Hansen JW (1998). Epidemiology, diagnosis and control of poultry parasites. FAO Animal Health Manual. Pp 50-115.

- Rahman MA, Hossain WIMA (1997). Introductory Animal Hygiene and Management. Department of Microbiology and Hygiene, Bangladesh Agricultural University, Mymensingh, Bangladesh: 7-34.

- Sahlu T, Dawson LJ, Gipson TA, Hart SP, Merkel RC (2009). ASAS Centennial paper: Impact of animal science research on United States goat production and prediction for the future. J. Anim. Sci. 87(1): 400-418. https://doi.org/10.2527/jas.2008-1291

- Seli E, Arici A (2002). Sex steroids and the immune system. Immunol. Allergy Clin. N. Am. 22(3): 407-433 .https://doi.org/10.1016/S0889-8561(02)00017-6

- Soulsby EJL (1982). Helminths, arthropods and protozoa of domesticated animals, 7th edn. Bailliere Tindall, UK, pp 136-354.

- Thrusfield, M (2005). Veterinary epidemiology, 2nd edn. Blackwell, UK. Pp 178-187.

- Vercruysse J, Claerebout E (2001). Treatment vs. nontreatment of helminth infections in cattle: defining the thresholds. Vet. Parasitol. 98(1-3): 195-214. https://doi. org/10.1016/S0304-4017(01)00431-9

- Yadav AK, Tandon V (1989). Gastrointestinal nematode infections of goats in a sub-tropical and humid zone of India. Vet. Parasitol. 33(2): 135-142. https://doi. org/10.1016/0304-4017(89)90061-7

- Wikipedia, 2014.http://en.wikipedia.org/wiki/Sylhet_District (accessed 08.11.14). 